Remineralizasyon

materyalleri ve

teknolojilerine güncel

bakış

\section{Current overview of remineralization materials and technologie}

Uzm. Dt. Gizem Demir

Gazi Üniversitesi Diş Hekimliği Fakültesi, Ankara, Türkiye Orcid ID: 0000-0002-9871-8226

Geliş tarihi: 01 Eylül 2019

Kabul tarihi: 01 Kasım 2019

doi: 10.5505/yeditepe.2020.16023

\section{Yazıșma adresi:}

Uzm. Dt. Gizem Demir Gazi Üniversitesi Diş Hekimliği Fakültesi, Ankara, Türkiye Gazi Üniversitesi Diş Hekimliği Fakültesi Restoratif

Diş Tedavisi A.D. Emek Mah. Bişkek Cad. No:4

A Blok 4. Kat 06500 Ankara

Tel: +903122035068

E-mail: gizemboztas@gazi.edu.tr
ÖZET

Toplumda oldukça yüksek oranda görülen diş çürüğünün önlenmesindeki en önemli koruyucu uygulama remineralizasyon tedavileridir. Florürün remineralizasyon tedavilerindeki başarısı çok sayıdaki çalışma tarafından kanıtlanmıştır ve hala altın standart olarak kabul görmektedir. Ancak olası yan etkileri nedeniyle araştırmacılar kullanılan florür konsantrasyonlarını azaltabilmek için, florürün etkinliğini arttırabilecek ya da florüre alternatif olabilecek yeni remineralizasyon yöntemlerinin arayışına girmiştir. Gelişen diş hekimliği teknolojileri remineralizasyonu artıran ve demineralizasyonu önleyen yeni materyal ve yöntemler bulunmuştur. Güncel yöntem ve teknolojiler mineral doygunluğunu arttıran materyalleri, mine ve dentinin rejenerasyonunu sağlayabileceği düşünülen biyomimetikleri, ozon ve lazer uygulamalarını, çürüğe neden olan bakteri plağını modifiye edebilen kimyasalları, çürük etkeni bakterilere etkili antiseptikleri ve remineralizasyonu arttırma potansiyeli olan doğal ürünleri içermektedir. Bu güncel yöntemlerin bazıları ile ilgili araştırmalar kısıtlı ve hala başlangıç seviyesinde iken bazılarının remineralizasyon etkinliği ile ilgili güçlü kanıtlar bulgulanmıştır. Bu derlemenin amacı; remineralizasyon tedavilerindeki güncel ve gelişen teknolojileri, bu yöntemlerin etki mekanizmalarını, remineralizasyon etkinliklerini ve klinik uygulamalarını, konuyla ilgili yapılan bilimsel araştırmaların sonuçları doğrultusunda değerlendirmek ve özetlemektir.

Anahtar kelimeler: Remineralizasyon, çürük, koruyucu diş hekimliği

\section{SUMMARY}

Remineralization therapies are the most important conservative applications in the prevention of dental caries. The success of fluoride in remineralization treatments has been proven by numerous studies and fluoride is still considered the gold standard. However, due to possible side effects, researchers have been researching new methods of remineralization that may increase the efficacy of fluoride or may be an alternative to fluoride in order to reduce the fluoride concentrations used. With the developing dental technologies, new materials and methods which increase remineralization and prevent demineralization have been found. These methods and technologies include materials that increase mineral saturation, biomimetics capable of regeneration of enamel and dentin, ozone and laser applications, bacterial plaque modifiers, antiseptics and natural products that have the potential to increase remineralization. Although, there is limited research on certain methods which is still in the initial phase, remineralization efficacy of others has been discovered with strong evidences. The purpose of this review is to evaluate and summarize the current technologies and developments in remineralization therapies, 
their mechanisms of action, their efficacy and clinical applications, in line with the results of scientific research. Keywords: Remineralization, dental caries, conservative dentistry

\section{GiRiş}

Diş çürüğü, diş sert dokularının hasar görmesine ve kaybına neden olan bulaşıcı bir mikrobiyolojik hastalıktır. Çürük; ağız içerisinde diş sert dokuları ile tükürük arasındaki iyon alışverişi sonucu oluşan demineralizasyon-remineralizasyon tepkimelerinden demineralizasyonun baskın hale gelmesi ile gerçekleşen dinamik bir süreçtir. ${ }^{1}$ Çürüğün önlenmesi, demineralizasyon-remineralizasyon dengesinin remineralizasyon yönüne kaydırılmasını temel alır. Diş remineralizasyonu süreci ile ilgili yapılan sayısız araştırmaların sonuçları; remineralizasyonu teşvik edebilen ve/veya demineralizasyonunu azaltabilen, ağız sağlığını olumlu yönde etkileyen teknolojilerin gelişmesine yol açmıştır. ${ }^{2}$ Başarısı birçok çalışma tarafından kanıtlanmış en etkili remineralizasyon ajanı florürdür. Birçok gelişmiş ülkede, son 25 yılda diş çürüğündeki azalmanın florürün sistemik ve topikal olarak yaygın bir şekilde kullanımı sayesinde olduğu düşünülmektedir. ${ }^{3}$ Remineralizasyonda altın standart olmasına rağmen, olası yan etkileri nedeniyle araştırmacılar kullanılan florür konsantrasyonlarını azaltabilmek için florürün etkinliğini arttırabilecek ya da florüre alternatif olabilecek yeni remineralizasyon yöntemlerinin arayışına girmiştir. Gelişen diş hekimliği teknolojileri ile remineralizasyonu artıran ve demineralizasyonu önleyen yeni materyal ve yöntemler bulunmuştur. ${ }^{4}$

$\mathrm{Bu}$ derlemenin amacı remineralizasyon tedavilerindeki yeni yöntem ve teknolojileri, bu yöntemlerin etki mekanizmalarını ve klinik uygulamalarını, konuyla ilgili yapılan bilimsel araştırmaların sonuçları doğrultusunda değerlendirmek ve özetlemektir.

\section{MINERAL DOYGUNLUĞUNU ARTIRAN MATERYALLER}

\section{Flor}

Günümüzde diş çürüklerini önlemek amacıyla en çok kullanılan remineralizasyon yöntemi flor uygulamalarıdır. Demineralizasyonun önüne geçen, remineralizasyonu arttıran flor sistemik ve topikal olarak uygulanabilmektedir. $^{5}$

Sistemik yolla alınan flor hidroksil gruplarıyla yer değiştirerek minenin yapısındaki hidroksil apatit kristallerinin yapısına girer ve flor apatit kristallerinin oluşumunu sağlar, bu yapı hidroksil apatit yapısından daha dirençlidir. Minenin asitlere karşı çözünürlüğü azalır. Sistemik flor uygulamasının etkisi pre-erüptiftir. Bununla birlikte, flor optimal dozun üzerinde alındığı takdirde, minenin gelişimi üzerine olumsuz etki gösterir ve dental florozise neden olur.

Topikal uygulamada florun etkileri çeşitlilik gösterir. Flor içeren maddeler anyonik maddelerdir ve negatif yüklü bakterilerle diş yüzeyindeki pozitif yüklü ligandlar için yarışırlar. Böylece proteinlerin ve bakterilerin mine yüzeyine birikimini engelleyerek, pelikıl ve plak formasyonunu önlerler. Flor iyonu tükürükteki kalsiyum ve fosfat iyonlarının diş yüzeyine çökelmesinde katalizör etki yapar ve hidroksiapatitin yapısını değiştirerek çürüğe karşı daha dirençli bir yapı olan florohidroksiapatit oluşumunu sağlar. ${ }^{6}$ Diğer etkisi ise antibakteriyel aktiviteye sahip olmasıdır. Flor iyonları özellikle düşük $\mathrm{pH}^{\prime}$ da bakteri hücresine girerek glikolitik yoldaki enolazı inhibe eder ve plaktaki asit üretimini azaltır. Yüksek konsantrasyondaki flor (12000 ppm) streptococcus mutans'ın da içinde olduğu bazı mikroorganizmalara direk toksik etki gösterir. ${ }^{7}$ Topikal uygulamalarda en çok kullanılan florlu bileşikler sodyum florür, kalsiyum florür, asidüle fosfat florürdür. ${ }^{8}$ Gümüş ve kalay metallerinin antibakteriyel özellikleri ile florun remineralizasyon etkisini birleştiren nano gümüş florür ${ }^{9}$, gümüş diamin florür ${ }^{10}$ ve kalay florür ${ }^{11}$ içeren topikal preparatlar da geliştirilmiştir.

\section{Kazein Fosfopeptit- Amorf Kalsiyum Fosfat (CPP-} ACP)

Kazein, sütte yüksek miktarda bulunan bir fosfoproteindir. 30-300 nm boyutunda olan kazein partikülleri yüksek oranda kalsiyum ve fosfor, daha az oranda magnezyum ve sitrat içerirler. Çürük önleyici etkinlik gösterebilmeleri için süt ve süt ürünlerinin çok yüksek miktarlarda tüketilmeleri gerekir. ${ }^{12}$ Bu nedenle araştırmacılar seçici çökelme yöntemini kullanarak kazeinin tripsin enzimi ile parçalanması sonucunda kazein fosfopeptidi (CPP) elde etmiştir. CPP kalsiyum fosfatı amorf kalsiyum fosfat (ACP) kompleksi olarak stabilize etme yeteneğine sahiptir. ACP, yüksek oranda doymamış bir kalsiyum fosfat çözeltisinden çökeltilen ve oktakalsiyum fosfat veya apatitik ürünler gibi kararlı kristal fazlara dönüştürebilen ilk katı fazdır. ACP'nin hidroksiapatite göre daha iyi in vivo osteoiletkenliğe, trikalsiyum fosfata göre daha iyi biyobozunurluğa ve biyoaktiviteye sahip olduğu ancak sitotoksik olmadığı bildirilmiştir. ${ }^{4,12,13}$

CPP'ye bağlı ACP, nötr iyon çifti dikalsiyumfosfat $(\mathrm{CaH}-$ PO4) da dahil olmak üzere kalsiyum ve fosfat iyonları rezervuarı görevi görür. Asidik koşullar altında, CPP'ye bağlı ACP, plak pH'sini tamponlar ve bunu yaparken $\mathrm{CaH}$ $\mathrm{PO}_{4}$ de dahil olmak üzere kalsiyum fosfat iyonlarına ayrışır. Dental plak bakterileri tarafından veya remineralizasyon sırasında hidroksiapatit oluşumu sırasında üretilen asit CPP/ACP için asidik koşulları sağladığı bildirilmiştir. ${ }^{13,14}$ Plak kalsiyum ve fosfat iyonlarındaki ve iyon çiftlerindeki artış, pH'daki herhangi bir düşüşü dengeler ve böylece mine demineralizasyonunu önlenir. Mineralizasyon sırasında $\mathrm{CaHPO}_{4}$ ve ilişkili kalsiyum ve fosfat iyonlarının protein ve su dolu demineralize mine gözenekleri yoluyla difüzyonu gerçekleşir. Bu kalsiyum ve fosfat türleri, ayrışma yoluyla $\mathrm{Ca}$ ve $\mathrm{PO}_{4}{ }^{3}$ - aktivitelerini arttırır ve böylece 
hidroksiapatitin doyma derecesini yükseltir. ${ }^{12,14-16}$ Hidroksiapatit oluşumu, nötr fosforik asit de dahil olmak üzere, asit ve fosfat oluşumuna yol açar ve CPP-ACP çözeltileri, mine remineralizasyonu sırasında üretilen asidi tüketeceklerinden daha fazla kalsiyum ve fosfat iyonları ayrışır. CPP, bağlı ACP rezervuarı aracılığıyla remineralizasyon sırasında serbest kalsiyum ve fosfat iyonlarının yüksek aktivitelerini sürdürür. Bu nedenle CPP-ACP verimli bir remineralizasyon ajanı olarak gösterilmiştir. ${ }^{2,14}$ Antikaryojenik potansiyeli ile ilgili yapılan laboratuvar, hayvan ve insan çalışmalarında CPP-ACP nanokomplekslerinin demineralizasyonu inhibe ederken, remineralizasyonu artırdığı gösterilmiştir., ${ }^{43,15-19}$ CPP-ACP'nin flor ile birlikte kullanımının remineralizasyon etkinliğini değerlendiren çalışmalara göre düşük konsantrasyondaki florür ve CPPACP'nin birlikte kullanımıyla, yüksek konsantrasyondaki florür kullanımı arasında anlamlı bir fark olmadığı ve kombinasyon tedavisi ile florür kullanımının azaltılabileceği sonucu çıkarılabilir. ${ }^{16,19,20}$ Literatürde CPP-ACP tedavisinin remineralizasyon tedavilerinde başarılı olduğunu gösteren güçlü kanıtlar mevcuttur ancak florür tedavilerine eşdeğer olduğunu kabul edebilmek için uzun dönem sonuçları değerlendiren daha fazla klinik çalışmalara intiyaç vardır.

\section{Biyoaktif Cam}

Biyomateryallerin biyoseramikler sınıfından olan biyoaktif camlar uzun yıllardır medikal olarak özellikle doku mühendisliği ve rejeneratif tıp alanında kullanılmaktadır. Biyoaktif cam insan vücudunda doğal olarak bulunan sodyum, kalsiyum, fosfor, silika (kalsiyum sodyum fosfosilikat) içerir ve hidroksil karbonat apatit oluşturmada biyoaktif yeteneğe sahiptir. ${ }^{21}$ Bu özellik sayesinde, biyoaktif camlar sert dokuya ve bazı durumlarda yumuşak dokuya kimyasal olarak bağlanabilmektedir. Bağlanma kabiliyeti temel olarak iki ana mekanizma ile açıklanabilir. ${ }^{22}$

1. Camdan sızan iyonlar, dokunun kolajen bağlanabilen hidroksil karbonat apatit oluşturur.

2. İyonlar, büyüme faktörlerini kodlayan ve osteojenik hücreleri kemik matriksi salgılaması için stimüle eden genleri düzenler.

Biyocam dokuların yenilenmesi ve işlevlerinin yeniden yapılandırılmasını başlatacak hücre sinyallerini etkilerken, in vivo olarak meydana gelen doğal mineralizasyon mekanizmalarını taklit eden bir biyomimetik mineralize edici olarak rol oynar. ${ }^{22,23}$

Araştırmacılar bioaktif camın diş hekimliğinde kullanım alanları ilgili çalışmalar yapmıştır. Bu çalışmalar sonucunda kemikte rejenerasyonu ve yeni ataçman sağlayabileceği için periodontolojide ${ }^{24}$, kemik ve bazı durumlarda yumuşak dokuya kimyasal bağlanabilme özelliğinden dolayı implantolojide ${ }^{25}$, çürük etkeni olan patojenler üzerindeki anlamlı antibakteriyel etkinliği ve biyoinert olması nedeniyle restoratif diş tedavisi ve endodontide ${ }^{26}$, dentin tübüllerindeki sıvı ile reaksiyona girerek mineralizasyonu uyardığı ve doğal bir tıkama oluşturabileceği için dentin hassasiyeti tedavisinde, pulpa histolojisini iyileştirebildiği ${ }^{24}$ ve mineralizasyonu uyardığı için kuafaj tedavisinde ${ }^{22}$ kullanabileceği bildirilmiştir.

Biyoaktif camların ostekondüktif olmaları ve apatit tabakası oluşturarak kemik dokuya kimyasal bağlanabilme yeteneği nedeniyle mine ve dentin yüzeylerinde mineralizasyon ajanı olarak kullanılabileceği düşünülmektedir. Dental kullanım için geliştirilen biyoaktif camın beyaz nokta lezyonları üzerindeki remineralizasyon etkinliğini değerlendirebilmek için birçok çalışma yapılmıştır ve olumlu sonuçlar gösterilmiştir. ${ }^{27-30}$

Biyoaktif camın tükürük veya herhangi bir fizyolojik sıvı ile temas ettiğinde apatit oluşumunu indükleme konusunda umut verici olduğu bildirilmiştir. Bu apatitin, eğer biyoaktif camın kimyasal bileşimine florür eklenmişse, hidroksi karbonat apatit veya florapatit oluşturabileceği, florür içeren camların düşük pH'lı ortamlarda artmış remineralizasyon aktivitesine sahip olduğu bulgulanmıştır. Mine demineralizasyonunu tedavi etmek için diş macununa, profilaktik jellere ve bazı ağız bakım ürünlerine çeşitli şekilde eklenmiştir. ${ }^{21-23}$ Bununla birlikte, biyoaktif camların remineralizasyonun indüklenmesindeki etkinliği ile ilgili sınırlı araştırma vardır. Yapılan in vitro çalışmalara dayanarak, biyoaktif camların mine remineralizasyonunu, florür ve CPP-ACP dahil olmak üzere diğer topikal remineralize edici maddelere göre daha etkili bir şekilde arttırdığı sonucu çıkarılabilir ancak konu ile ilgili klinik çalışmaların yapılması gereklidir. ${ }^{28-32}$

Dentin remineralizasyonu, bileşimindeki farklıı̆̆a bağlı olarak mine remineralizasyonundan daha zordur. Mine \%96'sı mineral apatitten oluştuğundan, bu dokunun mekanik özellikleri esas olarak mineral içeriği ile belirlenir. Dentinin mekanik özellikleri yalnızca genel mineral içeriğine değil, aynı zamanda kolajen yapı iskelesindeki minerallerin intrafibriller oryantasyonuna da bağlıdır. ${ }^{33}$

$\mathrm{Bu}$ nedenle, biyoaktif cam ile temas sonrası dokudaki mineral içeriğinin artması dentini remineralize etmek için yeterli değildir. Dentinde intrafibriller mineralizasyon yoluyla iyileşme, bu dokunun işlevselliğini korumak için çok önemlidir. Dentinin biyoaktif cam tarafından remineralizasyonu, pulpa kaynaklı odontoblast veya odontoblast benzeri hücrelerin, reaksiyoner veya reperatif dentin salgılayabilen uyarıcıları ile de tamamlanabilir. Ancak oluşabilecek yeni dentin sadece pulpa-dentin ara yüzü ile sınırlıdır ve konu ile ilgili araştırmalar başlangıç aşamasındadır. Bu nedenle dentinin hücresel olmayan bir şekilde, biyoaktif cam tarafından apatit oluşumu yoluyla remineralizasyonu ilgiyi üzerine toplamıştır. ${ }^{34}$

Dentin tübüllerinin tıkanması, dentin ara yüz bağlantısının iyileştirilmesi ve en önemlisi, mineral kaybına uğramış dentinin remineralizasyon yoluyla onarılması amacıyla bi- 
yoaktif camın restoratif materyallere eklenmesi konusunda araştırmalar yapılmaktadır. ${ }^{35-37}$

Konu ile ilgili yapılan araştırmalar incelendiğinde biyoaktif cam tedavisinin dentinde artmış apatit oluşumuna yol açtığı söylenebilir. ${ }^{38,39}$ Biyoaktif cam tozu parçacıklarının boyutu apatit oluşum oranını etkiler, nano biyoaktif cam tozlarının daha hızlı apatit oluşturan kinetiğe sahip olduğu bulgulanmıştır. ${ }^{40}$ Bununla birlikte, apatit oluşumu dentin remineralizasyonda önemli olan tek etmen değildir. Konuyla ilgili dentin mekanik özelliklerini değerlendiren çalışmalar kısıtıdır. Yeni apatit oluşumunun yanı sıra mineralize olmuş dentin mekanik özelliklerini incelemek için daha fazla araştırma gereklidir. Bu nedenle, biyoaktif camın dentin remineralize edebileceğini kanıtlayacak güçlü kanıtların olmadığı sonucuna varılabilir.

\section{4. İşlevselleştirilmiş $\beta$-Trikalsiyum Fosfat (fTCP)}

$\beta$-Trikalsiyum fosfat ( $\beta$-TCP) hidroksi apatit formasyonunda prekürsördür. Bu nedenle önemli bir kasiyum-fosfat sistemidir ve mineralize edici bileşenleri ile biyoaktif bir kaynak olarak hizmet eder. ${ }^{41} \beta$-TCP kristalli sistemin modifiye edilmesiyle elde edilen işlevselleştirilmiş $\beta$-trikalsiyum fosfat (fTCP) kalsiyumun iyonik flor ile erken etkileşime girmesini engeller ve düşük dozlu bir dağıtım sistemi görevi görebilir. ${ }^{41,42}$ fTCP ve flor birlikte kullanıldığında fTCP'nin tek başına kullanılmasına göre remineralizasyonda daha etkili olduğu gösterilmiştir. ${ }^{42}$ fTCP, CPP-ACP ve florür içeren diş macunlarının mine demineralizasyonunun önlenmesinde etkisinin değerlendirildiği başka bir çalışmada da en etkili kombinasyonun fTCP ve flor olduğu bulgulanmıştır. fTCP'nin flor içeren verniklere (NCT02341872) ve diş macunlarına (NCT02136576) eklenmesini değerlendiren devam eden kayıtlı klinik bir çalışmalar olsa da konuyla ilgili sonuçlanmış yeni bir klinik veri yoktur.

\section{Sodyum Trimetafosfat}

Trimetafosfat (TMP) organik bir polifosfat tuzudur. Hidroksiapatite ilgisi yüksektir ve mine yüzeyine bağlanabilir. Asit atakları sırasında, kristal yüzeylerde meydana gelen reaksiyonları koruyucu bir bariyer oluşturarak önler veya geciktirir. Mine yüzeyine bağlanabilen diğer aktif ajanlar gibi florürün etkisini artırır. Bu şekilde demineralizasyonu azalttığı remineralizasyonu olumlu yönde etkilediği düşünülmektedir. ${ }^{43-45} 1990$ 'lı yıllarda klinik olarak çalışıımış ve şu anda florun etkisini arttırma potansiyeli bakımından test edilmiştir. ${ }^{43-47}$ ìn situ veriler, flor içeren vernik $^{45}$ ve jellere ${ }^{48}$ sodyum florür içeren diş macununa ${ }^{44}$ TMP eklenmesinin remineralizasyon kabiliyetini artırabileceğini göstermiştir. Takeshita ve ark. ${ }^{43}$ yaptıkları çalışma sonucunda TMP içeren düşük flor konsantrasyonlu diş macununun standart flor konsantrasyonu içeren bir diş macununa benzer bir remineralizasyon kabiliyeti gösterdiğini bildirmişlerdir. Bu in situ veriler; bu teknolojinin remineralizasyonu arttırma potansiyeli olduğunu ve flor kullanımını azaltabileceğini açıkça gösterse de flor kullanımının endike olmadığı durumlarda klinik kullanımı ile ilgili öneride bulunabilmek için bu sonuçların klinik çalışmalar ile doğrulanması gerekir.

\section{Kalsiyum Gliserofosfat}

Organik bir fosfat olan kalsiyum gliserofosfat (CaGP) gliserofosforik asidin kalsiyum tuzudur. Kalsiyum ve fosfat kaynağı olan CaGP'ın pH tamponlama etkisi olduğu, plak hacminde azalma sağladığı, plaktaki kalsiyum ve fosfat seviyelerini arttırdığı için anti-çürük etkilere sahip olduğu düşünülmektedir. In vitro ${ }^{49-51}$ ve in situ çalışmalar ${ }^{52}$ gliserofosfat içeren flor konstantrasyonu düşük diş macunun çürük önleyici etkisinin standart florür konsantrasyonu olan diş macunundan daha fazla olduğunu göstermiştir. Konu ile ilgili yapılan bir in situ çalışma sonucunda CaGP eklenmiş düşük flor (500 ppm) konstantrasyonuna sahip diş macununun anti-çürük etkinliğinin standart miktarda (1100 ppm) florür içeren diş macununa göre daha etkili olduğu bildirilmiştir. ${ }^{52}$ FDA tarafından da besinlere eklenmesi genel olarak güvenli gıda maddesi (GRAS) olarak kabul edilmiş kalsiyum gliserofosfatın flor kullanımını azaltabilmek için oral ürünlere eklenebilecek iyi bir alternatif olabileceği düşünülmektedir.

\section{ANTISEPTIK MATERYALLER VE YÖNTEMLER}

Antibakteriyel ve antiplak özelliği olan bazı materyal ve yöntemlerin demineralizasyonu inhibe edebileceği, remineralizasyon sürecine katkı sağlayabileceği, florun etkisini arttırabileceği düşünülmektedir.

\section{Klorheksidin}

Klorheksidin, 1940'larda cilt yaraları için bir antiseptik olarak tanıtıldı ve geniş spektrumlu antibakteriyel etkileri nedeniyle diş hekimliğinde de yaygın olarak kullanılmaya başlandı. Gram-pozitif mikroorganizmalara gram negatif mikroorganizmalara göre daha etkili olan klorheksidin molekülü ağız mukozasına, mikroorganizmaya ya da pelikılın fosfat, karboksil veya sülfat gruplarına elektrostatik kuvvetlerle bağlanır. ${ }^{2}$ Bakteri hücre duvarlarını parçalayarak etki gösterir. Periodontal tedavide en etkili anti-plak ve anti-gingivitis ajanı, endodontik tedavide etkili bir antiseptik kök kanalı irrigantı olarak kullanılır. Restoratif diş hekimliğinde de klorheksidinin diş çürüğünün duraklatılmasında etkili olduğu bildirilmiştir. ${ }^{4}$ Flamee ve ark. ${ }^{53}$ klorheksidin ve flor içeren verniklerin çürük gelişimine etkilerinin değerlendirildikleri karşılaştırmalı çalışmaları sonucunda, iki materyal arasında istatistiksel olarak anlamlı bir fark bulgulamamışlardır, klorheksidin içeren verniğin çürük önleme etkisinin florürlü verniğe benzer olduğunu bildirmişlerdir. Klorheksidin ve florür içeren verniklerin tek başına ve birlikte kullanılmasının erken çürük lezyonları üzerindeki etkinliğinin değerlendirildiği klinik bir çalışma sonucunda florür ve klorheksidin ile tedavinin yeni başlayan lezyonların önlenmesinde daha başarılı olduğu bildirilmiştir. ${ }^{54}$ 
Son yapılan çalışmalar klorheksidinin sadece bakteriyel proteolitik enzimlerin aktivitesini inhibe etmediği aynı zamanda demineralize dişlerde proteazları inhibe ederek kolajen bozulmasını etkili bir şekilde azalttığı rapor edilmiştir. ${ }^{55,56}$ Rezin-dentin bağlanma dayanımı çalışmalarında çeşitli klorheksidin konsantrasyonları kullanılmış ve tüm bu konsantrasyonlarda matrix metallo proteinaz (MMP) inhibisyon etkisinin gözlendiği bildirilmiştir. Teorik olarak eğer kolajen fibril yapısı korunursa, tükürük veya diş tübüler sıvısından gelen kalsiyum ve fosfat iyonları ile demineralize dentin lezyonlarını remineralize etmek mümkün olabilir. ${ }^{55-57}$ Kim ve ark. ${ }^{58}$ demineralize dentin blokları üzerinde farklı klorheksidin konsantrasyonları kullanarak dentin remineralizasyonunu değerlendirmişler ve \% 0.2 ve $\% 2$ klorheksidin uygulanmasının dentin remineralizasyonunu olumlu yönde etkilediğini bulgulamışlardır. Klorheksidinin MMP inhibisyon etkisinin dentin remineralizasyonunda umut verici olduğu söylenebilir.

\section{Kitosan}

Kitosan, kitinin de-N-asetilasyonu ile hazırlanan bir polisakkarittir. Kitosan ve kitin yaygın olarak kabuklular, böcekler, mantar, yosun ve mayada mevcuttur. Kitosan ve türevlerinin doğal antibakteriyel ve antifungal özellikleri vardır. ${ }^{59}$ Fujiwara ve ark. ${ }^{60}$ yaptıkları çalışmada suda çözünebilen kitosanın özellikle Streptococcus mutans ve Lactobacillus brevis olmak üzere ağız bakterileri üzerine etkisini incelemiştir ve suda çözünebilen kitosanın çürükle ilgili olan Streptococcus mutans üzerine antibakteriyel etki gösterdiğini bildirmişlerdir. Arnaud ve ark. ${ }^{61}$, yaptıkları in vitro çalışma sonucunda kitosanın fosfor salınımını engelleyerek demineralizasyona müdahale ettiği, mine dentin bağlantı bölgesine kadar ilerleyerek asit ataklarına karşı bariyer gibi davrandığı ve demineralizasyonu engellediği bildirilmiştir. Yapılan son çalışmalarda rejenaratif biyomateryaller ile birlikte kullanımı değerlendirilmiş, amelogenin türevi peptit içeren kitosanın kardiyojenik bakterilerin inhibisyonu ve başlangıç çürük lezyonlarının remineralizasyonununu teşvik edebileceği, kitosan ve amorf kalsiyum fosfat nanokomplekslerinin demineralize minede mine kristaline benzer kristaller oluşturarak biyomineralizasyon sağlayabileceği, kitosan kolajen polimerlerin hidroksiapatit oluşumunu indükleyerek mine mineralizasyonunun şablonunu taklit edebileceği bildirilmiştir. ${ }^{62-64}$

\section{Lazer Uygulamaları}

Diş hekimliğinin birçok alanında kullanılan lazer çürüğün önlenmesinde de yardımcı bir yöntem olarak kullanılmaktadır. Yapılan çalışmalarda çeşitli lazer türlerinin minenin asitlere direnci ve demineralizasyonu üzerine etkisi araştırıımıştır. Lazer ışınının mine çubuklarında erime ve yeniden kristalleştirme oluşturarak mine üzerinde morfoloji değişikliklerine ve yüzeyde daha büyük hidroksiapatit kristallerinin oluşmasına neden olur ve bu yapı asit penetrasyonuna daha az geçirgendir. ${ }^{65,66} \mathrm{CO}_{2}$ lazerin dalga boyu mine ve dentin yapılarındaki fosfat, karbonat ve hidroksil gruplarının emilimi ile uyumlu olsa da diğer lazer türleri ile karşılaştırıldığı çalışmaların sonuçları çelişkilidir. Diğer lazer türlerine göre kanıtlanmış bir üstünlüğü olmadığı söylenebilir.65,67,68

Lazer ve şelasyon materyali beraber kullanıldığında kristallerin kompakt bir şekilde büyüdüğü ve bu kompakt kristal katmanın doğal mine prizmalarına benzer elastik modüle sahip olduğu bildirilmiştir. Lazer kullanımının mineralizasyonu hızlandırdığı, aynı zamanda kristal büyümesini de kontrol edebileceği düşünülmektedir. 67,69 Topikal florür tedavisi ile birleştirilen lazer ışınlamasının, florür alımını arttıran ve minenin çözünme oranını tek başına lazer veya florür uygulamasına kıyasla önemli ölçüde azaltan sinerjistik bir etki yarattığı gösteren çalışmalar olduğu gibi lazer uygulamasının belirgin remineralizasyon etkisinin olmadığı ve florun etkisini arttırmadığını da bulgulayan çalışmalar da mevcuttur. ${ }^{70-72}$ Ayrıca çeşitli lazer türlerinin CPP-ACP içeren remineralizasyon materyalleri ile birlikte kullanımı ile ilgili araştırmalar da yapıımıştır. Bazı araştırmacılar lazerin demineralize mine yüzeyindeki CPP-ACP'nin remineralizasyon etkisini arttırdığını bildirse de bazı çalışma sonuçlarına göre lazer ve CCP-ACP'nin birlikte kullanılmasının sinerjistik bir remineralizasyon etkisinin olmadığı gözlemlenmiştir. ${ }^{69,73}$ Lazerlerin tek başına ya da remineralizasyon materyalleri ile birlikte kullanımını değerlendiren birçok çalışma yapılmış olsa da sonuçlar çelişkilidir ve etkinliğinin kanıtlanabilmesi için daha fazla klinik araştırma yapılmasına intiyaç vardır.

\section{Ozon Uygulamaları}

Ozon stratosfer tabakasında bulunan, üç oksijen atomundan oluşan doğal bir gazdır. Ozon güçlü bir oksidan ve etkili bir antimikrobiyal ajandır. Ozonun gram negatif ve gram pozitif bakteri, virüs ve mantarlara karşı etkili olduğu kanıtlanmıştır. ${ }^{74}$ Diş hekimliğinde, ozonun antimikrobiyal etkilerini ve çürük önleme yeteneğini değerlendiren çok sayıda çalışma yapılmıştır. Klinik çalışmaların çoğu, ozonun çürük yönetimi için geleneksel yöntemlere ümit verici bir alternatif olduğunu bildirmiştir. ${ }^{74-76}$ Ozon gazının güçlü antibakteriyel özelliğinin yanı sıra güçlü okside edici özelliği sayesinde çürük lezyonundan etkilenen dokunun uzaklaştırılmadan remineralizasyon döngüsünün desteklenebileceğidir. Ozon, güçlü okside edici özelliği sayesinde, lezyonu koruyan protein tabakayı, tüm mikroorganizma ve ürünlerini ortadan kaldırarak ve sağlanan alkalen ortamda açık hale gelen dentin tübüllerine mineral yığıımını kolaylaştırarak gerçekleştirdiği rapor edilmiştir. Oluşan hipermineralize doku sonraki asit ataklarına karşı daha dirençli bir yapı kazanmaktadır. ${ }^{74-77}$ Birçok in vivo ve in vitro çalışmada ozonun antimikrobiyal ve okside edici özellikleri sayesinde, çürüğün tedavisi, kavite dezenfeksiyonu, diş plağındaki çürük ilişkili mikroorganizmaların 
seviyelerinin azaltılması ve çürük lezyonlarının remineralizasyonunda başarılı olduğu bildirilmiştir. ${ }^{75-77}$ Bununla birlikte, ozon uygulamasına yönelik klinik kanıtlar kapsamlı değildir. Bu nedenle, ozonun çürüğün yönetimi ve önlenmesi için mevcut yöntemlere bir alternatif olarak kabul edilmesinden önce daha fazla kanıt gerekmektedir.

\section{HIDROKSI APATIT VE DIĞER BIYOMIMEMTIKLER}

Florür ve benzeri güncel remineralizasyon ajanları organize apatit kristallerinin oluşumunu destekleme potansiyeline sahip değildir. Doku mühendisliği yöntemlerinde kaydedilen ilerlemelerin etkisiyle biyomineralizasyon ile mine rejenerasyonunu sağlayabilecek biyomimetik yöntemler araştırılmaya başlanmıştır. ${ }^{78}$

\section{Nano-Hidroksiapaptit}

Kemik ve dişlerin mineral kısmının ana bileşeni hidroksiapatit, kanıtlanmış biyolojik uyumluluğu nedeniyle tıp alanında en çok çalışılan biyo malzemeler arasında yer almaktadır. Son zamanlarda pek çok alanda nanoteknolojiye olan ilginin artmasıyla 50 ila $1000 \mathrm{~nm}$ arasında değişen kristaller sunan sentetik nano-hidroksi apatit geliştirilmiştir. ${ }^{78}$ Mine apatit kristal yapısına; morfolojik, yapısal ve kristalinite açısından benzerlik gösteren nano parçacıklar içeren bu sentetik biyomalzemenin koruyucu ve restoratif diş hekimliğinde kullanılabileceği düşünülmüş ve remineralizasyon etkinliğini değerlendiren çeşitli çalışmalar yapılmıştır. Mekanizması hala tam olarak bilinmeyen nano-hidroksi apaptitin küçük boyutları sayesinde etkinliği artmış nano parçacıkların demineralize mine üzerine çökeldiği aynı zamanda kalsiyum-fosfat deposu olarak görev yaparak oral süpersaturasyonu arttırdığı bildirilmiştir. ${ }^{78,79}$ Boyutlarından dolayı proteinlerin bağlanabileceği yüzey alanını önemli ölçüde artıran nanopartiküllerin, plak ve bakteri fragmanlarıyla bağlanma yeteneğine sahip olduğu gözlemlenmiştir. Bu mekanizmalarla asidik değişimleri kısıtladığı, demineralizasyonu önlediği ve remineralizasyonu arttırdığı düşünülmektedir. Remineralizasyonda altın standart olarak görülen florür var olan mine tabakasını güçlendirirken, biyomimetik nano-hidroksiapatitin işlevi diş çevresinde yeni bir sentetik mine tabakası oluşturmaktır. ${ }^{78-80}$

Nano-hidroksi apatit içeren diş macunları ve ağız gargaraları gibi ürünler 1980 'lerden beri mevcut olmasına rağmen, florürlü diş macunlardan üstün etkinliğe sahip olduğunu kanıtlayan iyi tasarlanmış bir randomize kontrollü çalışma yoktur. Ayrıca, nötr koşullar altında nano-hidroksiapatitin mine dış yüzeyinin remineralizasyonunu teşvik ettiği ancak lezyonun tamamında etkili olmadığı gösterilmiştir. ${ }^{81}$ Nanohidroksiapaptit içeren oral ürünlerin florürlü diş macunları veya gargaraların yerine önerebilmesi için daha fazla kanıt gereklidir.

\section{Amelogenin}

Amelogenin mine mineralizasyonu sırasında hidroksiapatit kristallerinin büyümesini, şeklini ve düzenini düzen- lemede kritik bir rol oynar. Bununla birlikte, olgun mine matris proteinlerinden yoksundur ve mineral kaybını yenileyemez. ${ }^{82}$ Sentetik amelogenin esaslı sistemler kullanarak karmaşık mine mikro yapısının çoğaltılabileceği düşünülmektedir. Rekombinant domuz amelogeninin (rP172), kalsiyum fosfat kümelerini stabilize ettiği, mine kristallerinin büyümesini teşvik ettiği, sertliğini ve elastik modülünü önemli ölçüde geliştirdiği bulunmuştur. ${ }^{82,83}$

Amelogenin düşük maliyetli ve daha güvenli bir alternatifi olan 56 amino asitten oluşan lösin bakımından zengin amelogenin peptidinin lezyon derinliğini düşürdüğünü ve c-ekseni boyunca olgun mine kristallerinin doğrusal büyümesini teşvik ederek mine biyomimetik rekonstrüksiyonunu sağladığı gösterilmiştir. ${ }^{84,85}$ Inorganik pirofosfat veya matris metaloproteinaz gibi mineralizasyon inhibitörleri eklenen sentetik amelogeninlerin yeni mineral katmanının boyutunu, şeklini ve oryantasyonunu daha iyi düzenleyebildiği bulgulanmıştır. ${ }^{85}$

Amelogenin elde edilmesi ve depolanması zordur ve amelogenin ile teşvik edilen mine tabakasının büyümesi uzun süre alır, bu nedenle klinik kullanım için uygun değildir. Ayrıca, amelogeninin vitro olarak apatit çekirdeklenmesini arttırdığı bulgulanmış olsa da, benzer biyomineralizasyonun in vivo olarak gerçekleştiğine dair doğrudan bir kanıt yoktur. ${ }^{82}$

\section{Poli amido amin dendrimerler}

Poli amido amin (PAMAM) dendrimerler bir dizi reaktif uç grup ve iç boşluklar içeren iyi tanımlanmış boyut ve şekle sahip amelogenin kaynaklı çok dallı polimerlerdir. ${ }^{86}$ Bu amelogenin kaynaklı dendrimerler, diş minesinin biomineralizasyonunu modüle etmede organik matrislerin fonksiyonlarını taklit edebildikleri için "yapay proteinler" olarak adlandırıımıştır. Birçok in vitro çalışma, amfifilik, karboksil ve fosfat uçlu PAMAM dendrimerlerin mine kristal yapılarına katılabildiği, PAMAM organik şablonlarının yarattığı yeni kristallerin, bozulmamış mine ile aynı yapıya, oryantasyona ve mineral faza sahip olduğu bulgulanmıştır. ${ }^{87,88}$

Amolegeninin elde edilmesi, saflaştırılması ve depolanması ile ilgili zorluklardan dolayı sentetik PAMAM dendrimerlerin biyomineralizasyonda amelogenin analoğu olarak kullanılabileceği düşünülse de yapılan in vivo çalışmalar hayvan deneyleriyle sınırlıdır. Ayrıca, amelogenin gibi, PAMAM aracılı biyoremineralizasyon da zaman alıcı bir işlemdir ancak süreci hızlandırmak ve kristal büyümesini kontrol etmek için lazerlerin kullanılabileceği düşünülmektedir. ${ }^{89}$

\section{Dentin Fosfoprotein Türevi 8DSS Peptitler}

Dentin fosfoprotein (DPP), dentindeki en bol miktarda kolajen olmayan hücre dışı matriks bileşenidir ve diş mineralizasyonunda kritik bir rol oynadığı bilinmektedir. biyomineralleşmeyi arttırmada en etkili DPP türevinin aspartat-serin-serin oktuplet tekrarları olan 8DDS peptidi 
olduğu bildirilmiştir. ${ }^{90}$ 8DDS peptidi $\mathrm{Ca}^{2+}$ ve $\mathrm{PO}_{4}^{3-}$ iyonlarının demineralize dentinden çözünmesini sınırlar, demineralize mine üzerinde yeni mineral birikintileri oluşturmak için bu iyonların yakalanmasını teşvik eder ve aynı zamanda hidroksiapatit yüzeyine de güçlü bir şekilde bağlanabilir. ${ }^{88}$ Bugüne kadar, 8DSS peptid kavramı sadece in vitro çalışmalarda gösterilmiştir ve klinik olarak kullanıldığında bu peptitlerin oral kavitede enzimatik etkiye dayanıp dayanamayacağı bilinmediği için bazı zorluklar ortaya çıkabilir. ${ }^{90,91}$

\section{P11-4 Peptitler}

Mine dokusu için en iyi rejeneratif yaklaşım, mine lezyonlarının derinlemesine remineralizasyonunu destekleyen biyomimetik mine matrisi oluşturabilmektir. ${ }^{92} \mathrm{Bu}$ alanda en heyecan verici gelişme, P11-4 olarak adlandırılan 11 amino asitten oluşan monomerik bir peptittir. P11-4 fibriller matrisi $\mathrm{Ca}^{2+}$ iyonları için yüksek bir afiniteye sahiptir, lezyon gövdesinin remineralizasyonu ile sonuçlanan hidroksiapaptit oluşumu için bir çekirdekleştirici olarak işlev görür ve tükrük kaynaklı doğal remineralizasyon oluşmasını sağlar. ${ }^{93}$ Yapılan in vitro çalışmalar, lezyon gövdesinde P11-4 varlığının, daha hızlı hidroksiapatit oluşumu sağladığı, oluşturduğu teğetsel olarak düzenlenmiş iğne şeklindeki kristaller ile remineralize yüzey altı lezyonunun mikro sertliğini arttırdığını göstermiştir. ${ }^{94}$ P11-4 in vivo ve klinik çalışmalarda biyomimetik mineralizasyon ajanı olarak ümit verici sonuçlar göstermiştir. Florürün remineralize etme etkinliğine bile direnç gösteren erken oklüzal ve proksimal lezyonları tersine çevirme yeteneğine sahip olduğu bulgulanmıştır. ${ }^{92,95}$ P11-4'ün rehberli mine rejenerasyonu yeteneğine sahip olduğu bildirilmiştir ancak bu bulguları doğrulamak ve onarım sürecini güçlendirebilecek diğer etmenleri belirlemek için daha uzun süreli kontrollü çalışmalara ihtiyaç vardır.

\section{Elektrikle Hızlandırılmış ve Geliştirilmiş Remineralizasyon}

Elektriksel olarak hızlandırılmış ve geliştirilmiş remineralizasyon (EAER) tüm sağlıklı dokuyu korumak, çürük lezyonunun tüm derinliğini geri kazandırmak ve minenin mekanik özelliklerini iyileştirmek amacıyla, tüm sağlıklı dokuyu tedavi etmeyi amaçlayan yakın zamanda geliştirilen bir remineralizasyon teknolojisidir. İyon akışını hızlandırmak için iyontoforezi kullanan bu sistem remineralizasyonunu destekleyen bir ortam yaratır. Biyomimetik peptitlerin aksine, EAER matris proteinleri veya $\mathrm{Ca}^{2+}$ ve $\mathrm{PO}_{4}^{3-}$ iyonlarının organik yakalanması yoluyla mineyi yeniden oluşturmaz. Ancak EAER ile tedavi edilen lezyonların kristal ve çubukların yapısı ve dizilimi açısından sağlıklı mineye çok benzer bir görünüme sahip olduğu bildirilmiştir. ${ }^{96}$ EAER teknolojisinin sentetik biyomimetik peptitlerden üstün yanı diş hekimliğinde yaygın olarak kullanılan araçlar ve kimyasallar aracılığıyla uygulanabil- ir olmasıdır. EAER teknolojisi ile ilgili in vitro sonuçlar oldukça ümit vericidir, ancak remineralizasyon potansiyelinin değerlendirilebilmesi vivo çalışmaların sonuçlarına bağlıdır. 96

\section{BIYOFILM MODIFIYE EDICILER}

\section{Arjinin}

Arjinin, insan tükürük proteinlerinde veya peptitlerinde bulunan yarı esansiyel bir amino asittir. Streptococcus sanguinis gibi patojenik olmayan bakteriler tarafından, arjinin deiminaz sistemi yoluyla enerji, amonyak ve karbondioksit üretmek için metabolize edilir. ${ }^{97}$ Amonyak üretimi $\mathrm{pH}$ 'ı arttırarak ve şeker metabolizması nedeniyle oluşan asidik ortamı nötralize eder ve karyojeniteyi azaltan daha alkali bir ortam sağlar. Ayrıca, yapısında bulunan pKa değeri 12.48 olan guanidyum grubu bazik, nötr ve hatta hafif asidik ortamlarda dahi pozitif yük taşıdığı gösterilmiştir. Arjijinin bu mekanizmaları nedeniyle çözünmeyen kalsiyum ve sodyum monoflorofosfat içeren diş macununa eklenmiştir. Arjinin flor ve kalsiyum içeren formülasyonunu arjinin olmayan formülasyonlarla remineralizasyon etkinliği açısından karşılaştıran birçok randomize klinik çalışma yapılmıştır ve arjinin içeren formülasyon daha başarılı olarak gösterilmiştir. Ancak arjininin anti-çürük etkinliğini değerlendiren bir sistematik derlemede mevcut kanıtların, yürütülen çalışmalarda ticari önyargı riskinin yüksek olması nedeniyle arjinin içeren diş macununu desteklemek için yetersiz olduğu sonucuna varmıştır. ${ }^{98}$

\section{Triklosan}

Triklosan geniş bir spektrumlu, antimikrobiyal bir maddedir, bununla birlikte aktivitesi konsantrasyona ve formülasyona bağlıdır. Triklosan, hem gram pozitif hem de gram negatif bakterileri, ayrıca birçok virüs ve mantarı inhibe edebilen için düşük konsantrasyonlarda geniş spektrumlu aktiviteye sahiptir. ${ }^{99}$ Biyofilm asit üretimini azaltması sonucunda mineral doygunluğunu arttırarak remineralizasyonu olumlu yönde etkiler. ${ }^{100}$

Antimikrobiyal özellikleri ve güvenli profili nedeniyle gingivitis ve diş çürüğüne neden olan bakteri türlerini baskılayabilmek için 1990'ların başında oral gargaralara ve diş macunlarına eklenmeye başlanmıştır. ${ }^{100,101} 1990$ 'ı ve 2000'li yıllarda yapılan büyük araştırmalar, diş macunu formülasyonuna triklosanın eklenmesinin çocuklarda ve yetişkinlerde koronal ve kök çürüğü insidansında istatistiksel olarak anlamlı azalmalar sağlayabileceğini göstermiş̧ir. ${ }^{100}$ Silva ve ark. ${ }^{101}$ yaptıkları bir in situ çalışma sonucunda triklosanın remineralizasyonda da etkili olabileceğini bildirmişlerdir. Yapılan başka bir araştırmada trik losan yüklü dendrimerlerin remineralizasyon potansiyeli olduğu gösterilmiştir, ancak bu yeni teknolojinin klinik verileri henüz mevcut değildir. ${ }^{102}$

\section{Ksilitol ve polioller}

Ksilitol, kayın ağaçlarından elde edilen 5 karbonlu doğal 
bir şekerdir. Sukroz molekülünün S.mutans'a bağlanmasını önler. S. Mutans ksilitolü fermente edemez. Ksilitol metabolik yollarını değiştirerek S. Mutans sayısını azaltır. ${ }^{5}$ Bahador ve ark. ksilitollü sakızların karyojenik bakteriler üzerine etkinliğini sorbitollü sakızlara göre değerlendiren çift kör randomize klinik bir çalışma yapmışlardır. Ksilitolün Streptococcus mutans ve Streptococcus sobrinus sayısını azalttığı ancak Streptococcus mitis ve Streptococcus sanguinis sayısında belirgin bir etki göstermediği rapor edilmiştir. Çalışma sonucunda ksilitolün tek başına karyojenik streptokok seviyelerini düşürdüğü bildirilmiştir. ${ }^{103}$ Bununla birlikte, ksilitol remineralizasyonu ile ilgili veriler çok daha azdır. Yapılan bir in situ çalışmada konsantrasyondaki ksilitollü verniğin remineralizasyon etkinliği değerlendirilmiş ve remineralizasyon tedavilerinde yeni bir seçenek olabileceği bildirilmiştir. ${ }^{104}$

Fermente edilemeyen veya yavaş bir şekilde fermente edilen diğer tatlandırıcıların da çürük önleme ve remineralizasyon etkileri incelenmiştir. Tatlandırıcı olarak yaygın kullanılan altı karbonlu şeker alkollerinden sorbitol ve mannitolün şeker yerine kullanıldığında çürüğü önleyebildiği bildirilmiştir. ${ }^{105}$ Ksilitol analoğu olan 4-karbonlu eritritolün değerlendirildiği çalışmalar sonucunda yüksek konsantrasyonda glikoz içeren bir kültür ortamında, mutans streptokokların çoğalmasını ksilitol gibi yavaşlattığı bulgulanmıştır. ${ }^{106,107}$ Eritritolün değerlendirildiği diğer bir klinik çalışma sonucunda çocuklardaki çürük lezyonlarını önlemedeki etkinliğinin ksilitolden daha fazla olduğu bildirilmiştir. ${ }^{108}$ Ksilitol ve diğer polioller umut verici remineralizasyon stratejileri olsa da, etkilerinin kanıtlanabilmesi için daha fazla klinik veri gereklidir.

\section{DOĞAL ÜRÜNLER}

\section{Teobromin}

Teobromin, teofilin ve kafein benzeri bileşikler içeren metil-ksantin ailesinin bir alkaloididir. Theobroma kakao ağacından elde edilen teobromin kakao ve çikolatada yüksek miktrarda bulunur. Kafeinin mineralizasyon üzerindeki etkisi araştırılırken tesadüfen mineralizasyona olumlu etkileri keşfedilen teobromin araştırmacıların ilgisini çekmiştir. ${ }^{109}$ Yapılan hayvan deneylerinin in-vitro sonuçları minedeki apatitin kristalliğini ve çözünme direncini arttırdığını göstermiştir. ${ }^{110}$ Teobrominin insan mine yüzeyindeki etkilerini in vitro olarak nasıl değiştirdiğini değerlendiren çalışmalar sonucunda teobrominin mine yüzeyinin mikro sertliğini, florüre göre büyük ölçüde arttırdığı gösterilmiştir. ${ }^{110,111}$ Ancak teobromin ve sodyum florürün mine lezyonlarındaki remineralizasyon potansiyelinin değerlendirildiği başka bir çalışmada teobrominin remineralizasyon potansiyelinin olduğu bulgulansa da bu etkinin florürden oldukça az olduğu bildirilmiştir. ${ }^{112}$ Dünya genelinde diş macunlarında yaygın olarak kullanılan teobromin floride alternatif olarak toksik olmayan bir bileşik olarak önerilse de etkinliğinin değerlendirilme- si için daha fazla çalışmaya intiyaç vardır.

\section{Hesperidin}

Diş dokusunun organik yapısının \%90'ını tip 1 kolajen lifler oluşturur. Remineralizasyon sürecinde kolajen yapılar iskelet görevi görür. Buna bağlı olarak kolajen liflerin korunmasının ve stabilizasyonunun bu süreçte gerekli olabileceği düşünülmektedir. Dentinde ve tükrükte bulunan matriks metalloproteinazlar dentindeki kolajenlerde bozunma yaratır. Farmakolojik araştırmalar sonucunda MMP aktivitesinin klorheksidin ile azaltılabildiği bildirilmiştir. Klorheksidinle benzer etkilere sahip olan doğal ürünler araştırılmaya başlamıştır. Hesperidin isimli bir maddenin benzer etkilere sahip olduğu bildirilmiştir. Hesperidin bir narenciyeden elde edilen bir maddedir. Antioksidan, antienflamatuar, antikarsinojenik, hipoglisemik etkisi olan kemik kaybını önleyen bir maddedir. ${ }^{113,114}$ Hiraishi ve ark. ${ }^{114}$ yaptıkları bir çalışmada hesperidinin sığır dentini üzerine etkilerini incelemişlerdir. Hesperidinin kolajeni koruduğu, proteolitik aktiviteyi azalttığı ayrıca dentinin asit demineralizasyonuna duyarılığını azalttığı ve remineralizasyon sürecini olumlu yönde etkilediğini bildirmişlerdir. Islam ve ark. ${ }^{114}$ ise klorheksidin, üzüm tohumu içeriği ve hesperidinin insan dentini üzerine etkilerini değerlendiren bir çalışma yapmışlardır. Hesperidin ve üzüm çekirdeği içeriği uygulanan grupta lezyon derinliği, kolajen bozulması ve mineral kaybı istatistiksel olarak anlamlı biçimde daha az izlenmiştir. Çalışma sonucunda hesperidinin demineralizasyonu engellediği ve remineralizasyonu florürsüz ortamlarda bile olumlu yönde etkileyebileceği bildirilmiştir. Hesperidinin dentin kolajenini stabilize ettiği, stabilize olan dokunun iyonların çıkışı için mekanik bariyer gibi görev yaptığı böylece demineralizasyonu engellediği; sağlam, stabilize bir kolajen yapının remineralizasyon için iskelet görevi gördüğü ve böylece remineralizasyon sürecini olumlu yönde etkilediği düşünülmektedir. ${ }^{113-115}$ Ancak konu ile ilgili çalışmalar oldukça kısıtlıdır ve hesperidinin remineralizasyon etkinliği ile ilgili sonuca varmak mümkün değildir.

\section{3. Üzüm Çekirdeği Özü}

Son yıllarda araştırmacılar oral hastalıkların önlenmesinde oral sağlığın geliştirilmesinde besinlerde bulunan içeriklerle ve geliştirilmiş besinsel ürünlerin kullanımı üzerine odaklı çalışmalar yapılmaktadır. Üzüm çekirdeği içeriği de ağız sağlığının geliştirilmesinde kullanılan doğal ürünlerden birisidir. Yüksek miktarda doğal bir antioksidan olan proantosyanidin içerir. Bu maddenin en önemli özelliği kolajen çapraz bağ sayısını artırarak kolajen içeren dokuları güçlendirebilmesidir. Ayrıca Streptococcus mutans'ın glikoziltranferaz aktivitesini ve asit üretimini inhibe etme özelliğine sahiptir. ${ }^{116}$ Xie ve ark. ${ }^{117}$ kök çürüklerinde üzüm çekirdeği içeriğinin remineralizasyona etkinliğinin değerlendirildiği bir çalışma yapmıştır. Çalışmada sodyum florür ile karşılaştırma yapılmış ve 
üzüm çekirdeği özünün remineralizasyonu pozitif etkilediği bildirilmiștir. Mekanizması flordan farklı olan üzüm çekirdeği özünün lezyonun yüzeysel tabakalarında mineral depolanmasını artırdığı, protoantosyanidin-kolajen etkileşimi ile kök dentinin organik yapısını etkilediği ve açık kolajen matriksi stabilize ettiği düşünülmektedir. ${ }^{117}$ Üzüm çekirdeği içeriğinin kök çürüklerindeki remineralizasyon etkinliğinin CPP-ACP ile karşılaştıııldığı başka bir in vitro çalışma sonucunda üzüm çekirdeği özünün demineralizasyonu önleyebilen ve remineralizasyonuna yardımcı olabilen doğal bir remineralizasyon ajanı olabileceği gösterilmiştir. ${ }^{118}$ Üzüm çekirdeği özünün mine remineralizasyonu etkinliğini değerlendiren çalışma sayısı kısıtlıdır ancak üzüm çekirdeği özünün mine demineralizasyonunu önlediği ve remineralizayonunu arttırdığı bulgulanmıştır. ${ }^{119}$ Olgun minenin kolajen içermeyen substrat olarak kabul edilir ancak birçok çalışma mine içerisinde tip I kolajen ve tip X kolajeninin bulunduğunu bildirmiştir. Üzüm çekirdeği özündeki protoantosyanidin, kolajen çapraz bağlarını arttıır. Üzüm çekirdeği özünün mine reminalizasyonundaki mekanizmasının eksojen kolajen çapraz bağları arttırması sonucu hidroksiapatit büyümesini teşvik etmesi ile ilgili olduğu düşünülmektedir. 116,119 Üzüm çekirdeği özü doğal bir remineralizasyon ajanı olarak umut verici olsa da konuyla ilgili daha fazla çalışma yapılması gereklidir.

\section{Galla Chinensis}

Galla chinensis (GCE) yaygın olarak kullanılan doğal ve geleneksel bir Çin ilacıdır. Rhus chinensis mill'in yapraklarının çin sumak biti tarafından parazitlenmesi sonucu ortaya çıkar. Galla chinensis antibakteriyel, antiviral, antioksidan, hepato koruyucu, anti-diyabetik, anti-trombin, anti-enflamatuar ve anti-tümör aktivitesi sergiler ayrıca çözünmeyen bileşikler oluşturmak için çeşitli metalik iyonlar, alkolsüz maddeler veya glikozitler ile birleştiğinden detoksifikasyon özelliklerine sahiptir. ${ }^{120}$

Diş hekimliğinde kullanımı ile ilgili son yıllarda çeşitli araştırmalar yapılmıştır. Galla Chinensis'in antibakteriyel etkinliği sayesinde s. mutans büyümesi, glukan sentezi ve agregasyonu üzerinde önemli inhibitör etkiye sahip olduğu ve anti-çürük ajanı olarak kullanılabileceği gösterilmiştir. Galla Chinensis'in polifenoller aracılığıyla organik matris ile etkileşime girdiği, asit atakları altında bile matrisin ayrışmasını engellediği ve kolajen bozulmasını önlediği gösterilmiştir. ${ }^{120,121} \mathrm{Bu}$ mekanizmalar ile mine ve dentinde demineralizasyonu önleyebileceği düşünülmektedir. Ayrıca yapısındaki kimyasal bileşiklerinin, kalsiyum iyonu taşıyıcıları olarak hareket ettiği, demineralize alanlara kalsiyum iyonları sağlayarak remineralizasyon etkisinin olabileceği bulgulanmıştır. Hidroksi apaptit yapısı ve oluşumunun değerlendirildiği bir in vitro çalışmada galla chinensis'in içeriğindeki gallik asitin hidroksiapait oluşum sürecinde düzenleyici etkisinin old- uğu ve remineralizasyonu olumlu yönde etkileyebileceği bildirilmiştir. ${ }^{121}$ Ayrıca flor ve nanohidroksi apatit içeren remineralizasyon ajanları ile birlikte kullanımı değerlendirilmiş ve sinerjistik etkiye sahip olduğu gösterilmiştir. ${ }^{122}$ Klinik kullanıma uyarlanabilmesi için toksikoloji testlerini de içeren ileri çalışmalara intiyaç vardır.

\section{Propolis}

Propolis arılar tarafından botanik kaynaklardan toplanan eksüdalardan elde edilir ve kovandaki boşlukları kapatarak dış etkenlere karşı korumak için kullanılır. Ayrıca, kovanın iç ortamını dezenfekte eder ve iç ortam sıcaklığını ayarlar. Bileşenleri arasında reçine ve balzamlar (\%50-70), balmumu (\%30-50), polenler (\%5-10), amino asitler, mineraller, A, B ve E vitaminleri, fenoller ve aromatik bileşikler bulunur. Reçineli kısmın büyük bir bölümünü oluşturan flavanoidler propolisin aktif bileşenidir ve antioksidan, antibakteriyel, antiviral, antifungal, antioksidan ve antienflamatuar özelliklerinin çoğundan sorumludurlar. ${ }^{123,124}$ Propolisin Streptococcus mutans ve Streptococcus sobrinus'un glikosiltransferaz enziminin aktivitesinin inhibe edebildiği in vivo ve in vitro olarak doğrulanmıştır. ${ }^{125,126}$ Ancak demineralizasyonu önleyici etkisini değerlendiren çalışmalarda kullanılan propolis tipleri birbirlerinden farklıdır ve sonuçlar çelişkilidir. ${ }^{127,128}$ Propolisin demineralizasyon önleme etkinliğinin değerlendirildiği ve farklı propolis tiplerinin antikaryojenik aktivitesinin karşılaştıııldığı daha fazla sayıda çalışmaya intiyaç vardır.

\section{SONUC}

Toplumda oldukça yüksek oranda görülen diş çürüğünün önlenmesindeki en önemli koruyucu uygulama remineralizasyon tedavileridir. Florun remineralizasyon tedavilerindeki başarısı çok sayıdaki çalışma tarafından kanıtlanmıştır ve hala altın standart olarak kabul görmektedir. Ancak olası yan etkileri nedeniyle artan olumsuz görüşler remineralizasyon tedavileri için yeni yaklaşımlar geliştirme intiyacını açıkça ortaya koymaktadır. Son yıllarda yapılan bilimsel araştırmalar sonucunda umut vaat eden birçok yeni strateji geliştirilmiş ve bazı doğal ürünlerin remineralizasyon potansiyeli olduğu gösterilmiş olsa da ulaşılabilirlik, kliniğe uygunluk, kullanım kolaylığı ve maliyet gibi sorunlar da vardır. Ayrıca çalışmalardan elde edilen kanıtlar florürün yerine geçebilecek yeni materyal veya yöntem ortaya koyabilmek için yeterli değildir. Diş sert dokularının rejenarasyonunu sağlanabileceği düşünülen biyomimetikler minimal girişimsel diş hekimliğinde remineralizasyon tedavilerinin geleceği gibi görünse de bu biyomateryaller hala geliştirilme aşamasındadır. Günümüzde kullanılan ve hala geliştirilme aşamasında olan remineralizasyon materyallerini ve yöntemlerini değerlendirdiğimiz bu derlemenin, konu ile ilgili gelecekte yapılacak çalışmalar için araştırmacılara yol gösterici olacağı kanaatindeyiz. 


\section{KAYNAKÇA}

1. Yon MJY, Gao SS, Chen KJ, Duangthip D, Lo ECM et al. Medical Model in Caries Management. Dent J. 2019;7(2):37.

2. Cochrane NJ, Cai F, Huq NL, Burrow MF, Reynolds EC. New Approaches to Enhanced Remineralization of Tooth Enamel. J Dent Res. 2010;89(11):1187-1197.

3. Lynch RJM, Smith SR. Remineralization Agents - New and Effective or Just Marketing Hype? Adv Dent Res. 2012;24(2):63-67.

4. Asokan S, Geethapriya P, Vijayasankari V. Effect of nonfluoridated remineralizing agents on initial enamel carious lesions: A systematic review. Indian J Dent Res. 2019;30(2):282.

5. Horst JA, Tanzer JM, Milgrom PM. Fluorides and Other Preventive Strategies for Tooth Decay. Dent Clin North Am. 2018;62(2):207-234.

6. Sharma D, Singh A, Verma K, Paliwal S, Sharma S, Dwivedi J. Fluoride: A review of pre-clinical and clinical studies. Environ Toxicol Pharmacol. 2017;56:297-313.

7. Van Loveren C. The Antimicrobial Action of Fluoride and its Role in Caries Inhibition. J Dent Res. 1990;69(2 suppl):676-681.

8. Weyant RJ, Tracy SL, Anselmo TT, et al. Topical fluoride for caries prevention: executive summary of the updated clinical recommendations and supporting systematic review. J Am Dent Assoc. 2013;144(11):1279-1291.

9. Burns J, Hollands K. Nano Silver Fluoride for preventing caries. Evid Based Dent. 2015;16(1):8-9.

10. Horst JA. Silver Fluoride as a Treatment for Dental Caries. Adv Dent Res. 2018;29(1):135-140.

11. Wierichs RJ, Lausch J, Meyer-Lueckel H, Esteves-Oliveira M. Re- and Demineralization Characteristics of Enamel Depending on Baseline Mineral Loss and Lesion Depth in situ. Caries Res. 2016;50(2):141-150.

12. Reema SD, Lahiri PK, Roy S Sen. Review of casein phosphopeptides-amorphous calcium phosphate. Chin J Dent Res. 2014;17(1):7-14.

13. Philip N, Walsh L. The potential ecological effects of casein phosphopeptide-amorphous calcium phosphate in dental caries prevention. Aust Dent J. 2019;64(1):6671.

14. Gurunathan D, Somasundaram S, Kumar S. Casein phosphopeptide-amorphous calcium phosphate: a remineralizing agent of enamel. Aust Dent J. 2012;57(4):404408.

15. Bijle MNA, Yiu CKY, Ekambaram M. Calcium-Based Caries Preventive Agents: A Meta-evaluation of Systematic Reviews and Meta-analysis. J Evid Based Dent Pract. 2018;18(3):203-217.e4.

16. Hegde S, Shetty D. Non-Fluoridated Remineralization Agents in Dentistry. https://www.researchgate.net/profile/Roma_E_M/publication/308098107_
Non-fluoridated_remineralization_agents_in_dentistry/ links/5a49e032458515f6b058f17b/Non-fluoridated-remineralization-agents-in-dentistry.pdf. Accessed July 3, 2019. 17. Mendes AC, Restrepo M, Bussaneli D, Zuanon AC. Use of Casein Amorphous Calcium Phosphate (CPP-ACP) on White-spot Lesions: Randomised Clinical Trial. Oral Health Prev Dent. 16(1):27-31.

18. Meyer-Lueckel $H$, Wierichs RJ, Schellwien $T$, Paris $S$. Remineralizing Efficacy of a CPP-ACP Cream on Enamel Caries Lesions in situ. Caries Res. 2015;49(1):56-62.

19. Thakkar $P$, Badakar $C$, Hugar $S$, Hallikerimath $S, P a-$ tel $\mathrm{P}$ et al. An in vitro comparison of casein phosphopeptide-amorphous calcium phosphate paste, casein phosphopeptide-amorphous calcium phosphate paste with fluoride and casein phosphopeptide-amorphous calcium phosphate varnish on the inhibition of demineralization an. J Indian Soc Pedod Prev Dent. 2017;35(4):312. 20. Rechmann $P$, Bekmezian $S$, Rechmann BMT, Chaffee BW, Featherstone JDB. MI Varnish and MI Paste Plus in a caries prevention and remineralization study: a randomized controlled trial. Clin Oral Investig. 2018;22(6):22292239.

21. Taha AA, Patel MP, Hill RG, Fleming PS. The effect of bioactive glasses on enamel remineralization: A systematic review. J Dent. 2017;67:9-17.

22. Fernando $D$, Attik N, Pradelle-Plasse N, Jackson $P$, Grosgogeat B, Colon P. Bioactive glass for dentin remineralization: A systematic review. Mater Sci Eng C. 2017;76:1369-1377.

23. Lizzi F, Villat $C$, Attik N, Jackson $P$, Grosgogeat $B$, Goutaudier C. Mechanical characteristic and biological behaviour of implanted and restorative bioglasses used in medicine and dentistry: A systematic review. Dent Mater. 2017;33(6):702-712.

24. Fernandes $H R$, Gaddam $A$, Rebelo $A$, Brazete $D$, Stan GE, Ferreira JMF. Bioactive Glasses and Glass-Ceramics for Healthcare Applications in Bone Regeneration and Tissue Engineering. Materials (Basel). 2018;11(12):2530. 25. Xuereb M, Camilleri J, Attard N. Systematic Review of Current Dental Implant Coating Materials and Novel Coating Techniques. Int J Prosthodont. 2015;28(1):5159.

26. Patel E, Pradeep $P$, Kumar $P$, Choonara YE, Pillay V. Oroactive dental biomaterials and their use in endodontic therapy. J Biomed Mater Res Part B Appl Biomater. April 2019:jbm.b.34379.

27. Bakry AS, Takahashi H, Otsuki M, Tagami J. Evaluation of new treatment for incipient enamel demineralization using 45S5 bioglass. Dent Mater. 2014;30(3):314-320.

28. Milly $H$, Festy $F$, Andiappan $M$, Watson TF, Thompson I, Banerjee A. Surface pre-conditioning with bioactive glass air-abrasion can enhance enamel white spot lesion remineralization. Dent Mater. 2015;31(5):522-533. 
29. Mehta $A B$, Kumari $V$, Jose $R$, Izadikhah V. Remineralization potential of bioactive glass and casein phosphopeptide-amorphous calcium phosphate on initial carious lesion: An in-vitro pH-cycling study. J Conserv Dent. 2014;17(1):3-7.

30. Milly H, Festy F, Watson TF, Thompson I, Banerjee A. Enamel white spot lesions can remineralise using bio-active glass and polyacrylic acid-modified bio-active glass powders. J Dent. 2014;42(2):158-166.

31. Palaniswamy UK, Prashar N, Kaushik M, Lakkam SR, Arya S, Pebbeti S. A comparative evaluation of remineralizing ability of bioactive glass and amorphous calcium phosphate casein phosphopeptide on early enamel lesion. Dent Res J (Isfahan). 2016;13(4):297.

32. Narayana SS, Deepa VK, Ahamed S, Sathish ES, Meyappan R, Satheesh Kumar KS. Remineralization efficiency of bioactive glass on artificially induced carious lesion an in-vitro study. J Indian Soc Pedod Prev Dent. 2014;32(1):19-25.

33. Bertassoni LE, Habelitz S, Kinney JH, Marshall SJ, Marshall GW, Jr. Biomechanical perspective on the remineralization of dentin. Caries Res. 2009;43(1):70-77.

34. Fernando D, Attik N, Pradelle-Plasse N, Jackson P, Grosgogeat B, Colon P. Bioactive glass for dentin remineralization: A systematic review. Mater Sci Eng C. 2017;76:1369-1377.

35. Chatzistavrou X, Velamakanni S, DiRenzo K, et al. Designing dental composites with bioactive and bactericidal properties. Mater Sci Eng C. 2015;52:267-272.

36. Osorio E, Fagundes T, Navarro MF, et al. A novel bioactive agent improves adhesion of resin-modified glass-ionomer to dentin. 2015; 29:1543-1552.

37. Tauböck TT, Zehnder M, Schweizer T, Stark WJ, Attin $\mathrm{T}$, Mohn D. Functionalizing a dentin bonding resin to become bioactive. Dent Mater. 2014;30(8):868-875.

38. Wang $Z$, Jiang $T$, Sauro $S$, et al. Dentine remineralization induced by two bioactive glasses developed for air abrasion purposes. J Dent. 2011;39(11):746-756.

39. Wang Z, Shen Y, Haapasalo M, et al. Polycarboxylated microfillers incorporated into light-curable resin-based dental adhesives evoke remineralization at the mineral-depleted dentin. J Biomater Sci Polym Ed. 2014;25(7):679-697.

40. Vollenweider M, Brunner TJ, Knecht $S$, et al. Remineralization of human dentin using ultrafine bioactive glass particles. Acta Biomater. 2007;3(6):936-943.

41. Ekambaram M, Mohd Said SNB, Yiu CKY. A Review of Enamel Remineralisation Potential of Calcium- and Phosphate-based Remineralisation Systems. Oral Health Prev Dent. 15(5):415-420.

42. Karlinsey RL, Pfarrer AM. Fluoride Plus Functionalized B-TCP. Adv Dent Res. 2012;24(2):48-52.

43. Takeshita EM, Danelon M, Castro LP, Cunha RF,
Delbem ACB. Remineralizing Potential of a Low Fluoride Toothpaste with Sodium Trimetaphosphate: An in situ Study. Caries Res. 2016;50(6):571-578.

44. Danelon M, Pessan JP, Neto FNS, de Camargo ER, Delbem ACB. Effect of toothpaste with nano-sized trimetaphosphate on dental caries: In situ study. J Dent. 2015;43(7):806-813.

45. Manarelli MM, Delbem ACB, Lima TMT, Castilho FCN, Pessan JP. In vitro Remineralizing Effect of Fluoride Varnishes Containing Sodium Trimetaphosphate. Caries Res. 2014;48(4):299-305.

46. Hirata E, Danelon M, Freire IR, Delbem ACB. In Vitro Enamel Remineralization by Low-Fluoride Toothpaste with Calcium Citrate and Sodium Trimetaphosphate. Braz Dent J. 2013;24(3):253-257.

47. Danelon M, Takeshita EM, Peixoto LC, Sassaki KT, Delbem ACB. Effect of fluoride gels supplemented with sodium trimetaphosphate in reducing demineralization. Clin Oral Investig. 2014;18(4):1119-1127.

48. Danelon M, Takeshita EM, Peixoto LC, Sassaki KT, Delbem ACB. Effect of fluoride gels supplemented with sodium trimetaphosphate in reducing demineralization. Clin Oral Investig. 2014;18(4):1119-1127.

49. Carvalho TS, Bönecker $M$, Altenburger MJ, Buzalaf MAR, Sampaio FC, Lussi A. Fluoride varnishes containing calcium glycerophosphate: fluoride uptake and the effect on in vitro enamel erosion. Clin Oral Investig. 2015;19(6):1429-1436.

50. CARVALHO TS, PETERS BG, RIOS D, et al. Fluoride varnishes with calcium glycerophosphate: fluoride release and effect on in vitro enamel demineralization. Braz Oral Res. 2015;29(1):1-6.

51. Barbosa CS, Montagnolli LG, Kato MT, Sampaio FC, Buzalaf MAR. Calcium glycerophosphate supplemented to soft drinks reduces bovine enamel erosion. J Appl Oral Sci. 20(4):410-413.

52. Zaze ACSF, Dias AP, Amaral JG, Miyasaki ML, Sassaki KT, Delbem ACB. In situ evaluation of low-fluoride toothpastes associated to calcium glycerophosphate on enamel remineralization. J Dent. 2014;42(12):1621-1625. 53. Flamee $S$, Gizani $S$, Caroni $C$, Papagiannoulis $L$, Twetman S. Effect of a chlorhexidine/thymol and a fluoride varnish on caries development in erupting permanent molars: a comparative study. Eur Arch Paediatr Dent. 2015;16(6):449-454.

54. Naidu S, Tandon S, Nayak R, Ratnanag PV, Prajapati D, Kamath N. Efficacy of Concomitant Therapy with Fluoride and Chlorhexidine Varnish on Remineralization of Incipient Lesions in Young Children. Marwah N, ed. Int J Clin Pediatr Dent. 2016;9(4):296-302.

55. Hebling J, Pashley DH, Tjäderhane L, Tay FR. Chlorhexidine arrests subclinical degradation of dentin hybrid layers in vivo. J Dent Res. 2005;84(8):741-746. 
56. De Munck J, Van den Steen PE, Mine A, et al. Inhibition of enzymatic degradation of adhesive-dentin interfaces. J Dent Res. 2009;88(12):1101-1106.

57. Maske TT, Kuper NK, Cenci MS, Huysmans M-CDNJM. Chlorhexidine, a Matrix Metalloproteinase Inhibitor and the Development of Secondary Caries Wall Lesions in a Microcosm Biofilm Model. Caries Res. 2019;53(1):107117.

58. Kim D-S, Kim J, Choi K-K, Kim S-Y. The influence of chlorhexidine on the remineralization of demineralized dentine. J Dent. 2011;39(12):855-862.

59. Cicciù M, Fiorillo L, Cervino G. Chitosan Use in Dentistry: A Systematic Review of Recent Clinical Studies. Mar Drugs. 2019;17(7):417.

60. Fujiwara M, Hayashi Y, Ohara N. Inhibitory effect of water-soluble chitosan on growth of Streptococcus mutans. New Microbiol. 2004;27(1):83-86.

61. Arnaud TMS, de Barros Neto B, Diniz FB. Chitosan effect on dental enamel de-remineralization: $A n$ in vitro evaluation. J Dent. 2010;38(11):848-852.

62. Xiao Z, Que K, Wang $H$, et al. Rapid biomimetic remineralization of the demineralized enamel surface using nano-particles of amorphous calcium phosphate guided by chimaeric peptides. Dent Mater. 2017;33(11):1217-1228. 63. Zhang $X$, Li Y, Sun $X$, et al. Biomimetic remineralization of demineralized enamel with nano-complexes of phosphorylated chitosan and amorphous calcium phosphate. J Mater Sci Mater Med. 2014;25(12):2619-2628.

64. Ren Q, Ding L, Li Z, et al. Chitosan hydrogel containing amelogenin-derived peptide: Inhibition of cariogenic bacteria and promotion of remineralization of initial caries lesions. Arch Oral Biol. 2019;100:42-48.

65. Soltanimehr E, Bahrampour E, Yousefvand Z. Efficacy of diode and $\mathrm{CO} 2$ lasers along with calcium and fluoride-containing compounds for the remineralization of primary teeth. BMC Oral Health. 2019;19(1):121.

66. Poosti $M$, Ahrari $F$, Moosavi $H$, Najjaran $H$. The effect of fractional $\mathrm{CO} 2$ laser irradiation on remineralization of enamel white spot lesions. Lasers Med Sci. 2014;29(4):1349-1355.

67. Berger SB, Cavalli V, Ambrosano GMB, Giannini M. Changes in surface morphology and mineralization level of human enamel following in-office bleaching with $35 \%$ hydrogen peroxide and light irradiation. Gen Dent. 58(2):e74-9.

68. Santos DM, Nogueira RD, Lepri CP, Gonçalves LS, Palma-Dibb RG, et al. In vitro assessment of the acid resistance of demineralized enamel irradiated with Er, Cr:YSGG and Nd:YAG lasers. Pediatr Dent. 36(7):137-142.

69. Farhadian N, Rezaei-Soufi L, Jamalian SF, et al. Effect of CPP-ACP paste with and without $\mathrm{CO} 2$ laser irradiation on demineralized enamel microhardness and bracket shear bond strength. Dental Press J Orthod.
2017;22(4):53-60.

70. Ahrari F, Mohammadipour H, Hajimomenian L, Fallah-Rastegar A. Evaluation the effect of the diode laser irradiation associated with photoabsorbing cream containing remineralizing agents on microhardness, morphology and the chemical structure of early enamel caries. J Clin Exp Dent. 2018;10(10):e955-e962.

71. Soltanimehr E, Bahrampour E, Yousefvand Z. Efficacy of diode and $\mathrm{CO} 2$ lasers along with calcium and fluoride-containing compounds for the remineralization of primary teeth. BMC Oral Health. 2019;19(1):121.

72. Fekrazad R, Najafi A, Mahfar R, Namdari M, Azarsina M. Comparison of enamel remineralization potential after application of titanium tetra fluoride and carbon dioxide laser. LASER Ther. 2017;26(2):113-119.

73. Khamverdi Z, Kordestani M, Panahandeh N, Naderi F, Kasraei S. Influence of CO2 Laser Irradiation and CPPACP Paste Application on Demineralized Enamel Microhardness. J Lasers Med Sci. 2018;9(2):144-148.

74. Gupta G, Mansi B. Ozone therapy in periodontics. J Med Life. 2012;5(1):59-67.

75. Tandan M, Gupta S, Tandan P. Ozone in Conservative Dentistry \& Endodontics: A Review. Int J Clin Prev Dent. 2012;8(1):29-35.

76. Almaz ME, Sönmez IŞ. Ozone therapy in the management and prevention of caries. J Formos Med Assoc. 2015;114(1):3-11.

77. Boztaş G, Ömürlü H. Restoratif Diş Hekimliğinde Ozon Tedavileri. Atatürk Üniversitesi Diş Hekim Fakültesi Derg. 2015;9(9).

78. Niu L-N, Zhang W, Pashley DH, et al. Biomimetic remineralization of dentin. Dent Mater. 2014;30(1):77-96.

79. Juntavee N, Juntavee A, Plongniras P. Remineralization potential of nano-hydroxyapatite on enamel and cementum surrounding margin of computer-aided design and computer-aided manufacturing ceramic restoration. Int J Nanomedicine. 2018;13:2755-2765.

80. Nozari A, Ajami S, Rafiei A, Niazi E. Impact of Nano Hydroxyapatite, Nano Silver Fluoride and Sodium Fluoride Varnish on Primary Teeth Enamel Remineralization: An In Vitro Study. J Clin Diagn Res. 2017;11(9):ZC97-ZC100. 81. Huang S, Gao S, Cheng L, Yu H. Remineralization Potential of Nano-Hydroxyapatite on Initial Enamel Lesions: An in vitro Study. Caries Res. 2011;45(5):460-468.

82. Ruan Q, Moradian-Oldak J. Amelogenin and enamel biomimetics. J Mater Chem B. 2015;3(16):3112-3129.

83. Fan Y, Sun Z, Moradian-Oldak J. Controlled remineralization of enamel in the presence of amelogenin and fluoride. Biomaterials. 2009;30(4):478-483.

84. Hossein BG, Sadr A, Espigares J, et al. Study on the influence of leucine-rich amelogenin peptide (LRAP) on the remineralization of enamel defects via micro-focus x-ray computed tomography and nanoindentation. 
Biomed Mater. 2015;10(3):035007.

85. Kwak SY, Litman A, Margolis HC, Yamakoshi $Y$, Simmer JP. Biomimetic Enamel Regeneration Mediated by Leucine-Rich Amelogenin Peptide. J Dent Res. 2017;96(5):524-530.

86. Chen J, Cao X, Guo R, et al. A highly effective polymerase chain reaction enhancer based on dendrimer-entrapped gold nanoparticles. Analyst. 2012;137(1):223228.

87. Chen L, Yuan $H$, Tang B, Liang K, Li J. Biomimetic Remineralization of Human Enamel in the Presence of Polyamidoamine Dendrimers in vitro. Caries Res. 2015;49(3):282-290.

88. Hsu CC, Chung HY, Yang J-M, Shi W, Wu B. Influence of 8DSS Peptide on Nano-mechanical Behavior of Human Enamel. J Dent Res. 2011;90(1):88-92.

89. Sun M, Wu N, Chen H. Laser-assisted Rapid Mineralization of Human Tooth Enamel. Sci Rep. 2017;7(1):9611. 90. Yarbrough DK, Hagerman E, Eckert R, et al. Specific Binding and Mineralization of Calcified Surfaces by Small Peptides. Calcif Tissue Int. 2010;86(1):58-66.

91. Chen M, Yang J, Li J, et al. Modulated regeneration of acid-etched human tooth enamel by a functionalized dendrimer that is an analog of amelogenin. Acta Biomater. 2014; 10(10):4437-4446. 6

92. Alkilzy M, Santamaria RM, Schmoeckel J, Splieth $\mathrm{CH}$. Treatment of Carious Lesions Using Self-Assembling Peptides. Adv Dent Res. 2018;29(1):42-47.

93. Kind L, Stevanovic $S$, Wuttig S, et al. Biomimetic Remineralization of Carious Lesions by Self-Assembling Peptide. J Dent Res. 2017;96(7):790-797.

94. Takahashi F, Kurokawa H, Shibasaki S, Kawamoto R, Murayama R, Miyazaki M. Ultrasonic assessment of the effects of self-assembling peptide scaffolds on preventing enamel demineralization. Acta Odontol Scand. 2016;74(2):142-147.

95. Schlee M, Schad T, Koch JH, Cattin PC, Rathe F. Clinical performance of self-assembling peptide $P 11$ -4 in the treatment of initial proximal carious lesions: A practice-based case series. J Investig Clin Dent. 2018;9(1):e12286.

96. Pitts NB, Wright JP. Reminova and EAER: Keeping Enamel Whole through Caries Remineralization. Adv Dent Res. 2018;29(1):48-54.

97. Wijeyeweera RL, Kleinberg I. Arginolytic and ureolytic activities of pure cultures of human oral bacteria and their effects on the $\mathrm{pH}$ response of salivary sediment and dental plaque in vitro. Arch Oral Biol. 1989;34(1):43-53.

98. Ástvaldsdóttir Á, Naimi-Akbar A, Davidson T, et al. Arginine and Caries Prevention: A Systematic Review. Caries Res. 2016;50(4):383-393.

99. Schweizer HP. Triclosan: a widely used biocide and its link to antibiotics. FEMS Microbiol Lett. 2001;202(1):1-
7.

100. Riley P, Lamont T. Triclosan/copolymer containing toothpastes for oral health. In: Riley P, ed. Cochrane Database of Systematic Reviews. Chichester, UK: John Wiley \& Sons, Ltd; 2013:CD010514.

101. Silva MFDA, Giniger MS, Zhang YP, Devizıo W. The effect of a triclosan/copolymer/fluoride liquid dentifrice on interproximal enamel remineralization and fluoride uptake. J Am Dent Assoc. 2004;135(7):1023-1029.

102. Zhou Y, Yang J, Lin Z, et al. Triclosan-loaded poly(amido amine) dendrimer for simultaneous treatment and remineralization of human dentine. Colloids Surfaces B Biointerfaces. 2014;115:237-243.

103. Bahador A, Lesan S, Kashi N. Effect of xylitol on cariogenic and beneficial oral streptococci: a randomized, double-blind crossover trial. Iran $\mathrm{J}$ Microbiol. 2012;4(2):75-81.

104. Cardoso JG, lorio NLP, Rodrigues LF, et al. Influence of a Brazilian wild green propolis on the enamel mineral loss and Streptococcus mutans' count in dental biofilm. Arch Oral Biol. 2016;65:77-81.

105. Birkhed D, Edwardsson S, Ahldén ML, Frostell G. Effects of 3 months frequent consumption of hydrogenated starch hydrolysate (Lycasin), maltitol, sorbitol and xylitol on human dental plaque. Acta Odontol Scand. 1979;37(2):103-115.

106. Mäkinen KK, Isotupa KP, Kivilompolo T, Mäkinen $P L$, Toivanen J, Söderling E. Comparison of Erythritol and Xylitol Saliva Stimulants in the Control of Dental Plaque and Mutans Streptococci. Caries Res. 2001;35(2):129-135.

107. Lenkkeri a-mh, pienihakkinen k, hurmr s, alanen $\mathrm{p}$. The caries-preventive effect of xylitol/maltitol and erythritol/maltitol lozenges: results of a double-blinded, cluster-randomized clinical trial in an area of natural fluoridation. Int J Paediatr Dent. 2012;22(3):180-190.

108. Honkala S, Runnel $R$, Saag $M$, et al. Effect of erythritol and xylitol on dental caries prevention in children. Caries Res. 2014;48(5):482-490.

109. Cova I, Leta V, Mariani C, Pantoni L, Pomati S. Exploring cocoa properties: is theobromine a cognitive modulator? Psychopharmacology (Berl). 2019;236(2):561-572. 110. Amaechi BT, Porteous N, Ramalingam K, Mensinkai PK, Cchahuana Vasquez RA, et al. Remineralization of Artificial Enamel Lesions by Theobromine. Caries Res. 2013;47(5):399-405.

111. Kargul B, Özcan M, Peker S, Nakamoto T, Simmons WB FA. Evaluation of human enamel surfaces treated with theobromine: a pilot study. - PubMed - NCBI. Oral Heal Prev Dent. 2012:10(3):275-282.

112. Lippert $F$. The effects of fluoride, strontium, theobromine and their combinations on caries lesion rehardening and fluoridation. Arch Oral Biol. 2017;80:217-221. 113. Islam SM, Hiraishi N, Nassar M, Sono R, Otsuki M, et 
al. In vitro effect of hesperidin on root dentin collagen and de/re-mineralization. Dent Mater J. 2012;31(3):362-367.

114. Hiraishi N, Sono R, Islam MS, Otsuki M, Tagami J, et al. Effect of hesperidin in vitro on root dentine collagen and demineralization. J Dent. 2011;39(5):391-396.

115. Van Strijp AJP, Takatsuka T, Sono R, lijima Y. Inhibition of dentine collagen degradation by hesperidin: an in situ study. Eur J Oral Sci. 2015;123(6):447-452.

116. Jawale KD, Kamat SB, Patil JA, Nanjannawar GS, Chopade RV. Grape seed extract: An innovation in remineralization. J Conserv Dent. 2017;20(6):415-418.

117. Xie $Q$, Bedran-Russo AK, Wu CD. In vitro remineralization effects of grape seed extract on artificial root caries. J Dent. 2008;36(11):900-906.

118. Prabhakar AR, Sharma D, Sugandhan S. Comparative evaluation of the remineralising effects and surface microhardness of glass ionomer cement containing grape seed extract and casein phosphopeptide -amorphous calcium phosphate: an in vitro study. Eur Arch Paediatr Dent. 2012;13(3):138-143.

119. Nagi S, Hassan S, Abd El-Alim S, Elmissiry M. Remineralization potential of grape seed extract hydrogels on bleached enamel compared to fluoride gel: An in vitro study. J Clin Exp Dent. 2019:e401-e407.

120. Zhang T, Chu J, Zhou X. Anti-carious Effects of Galla chinensis: A Systematic Review. Phyther Res. 2015;29(12):1837-1842.

121. Tang $B$, Yuan $H$, Cheng $L$, Zhou $X$, Huang $X$, Li J. Effects of gallic acid on the morphology and growth of hydroxyapatite crystals. Arch Oral Biol. 2015;60(1):167-173. 122. Zhang TT, Guo HJ, Liu XJ, Chu JP, Zhou XD. Galla chinensis Compounds Remineralize Enamel Caries Lesions in a Rat Model. Caries Res. 2016;50(2):159-165.

123. Abbasi AJ, Mohammadi F, Bayat $M$, Gema SM, Ghadirian $\mathrm{H}$, et al. Applications of propolis in Dentistry: A review. Ethiop J Heal Sci. 2018;28(4):509.

124. Dziedzic A, Kubina R, Wojtyczka RD, Kabała-Dzik A, Tanasiewicz M, Morawiec T. The antibacterial effect of ethanol extract of polish propolis on mutans streptococci and lactobacilli isolated from saliva. Evid Based Complement Alternat Med. 2013; Article ID:681891.

125. Duailibe SA de C, Gonçalves AG, Ahid FJM. Effect of a propolis extract on Streptococcus mutans counts in vivo. J Appl Oral Sci. 2007; 15(5):420-423.

126. Koo $H$, Rosalen $P L$, Cury JA, Park YK, Bowen WH. Effects of compounds found in propolis on Streptococcus mutans growth and on glucosyltransferase activity. Antimicrob Agents Chemother. 2002;46(5):1302-1309. 127. Cardoso JG, lorio NLP, Rodrigues LF, Couri MLB, Farah A, et al. Influence of a Brazilian wild green propolis on the enamel mineral loss and Streptococcus mutans' count in dental biofilm. Arch Oral Biol. 2016;65:77-81.

128. Martins ML, Leite KL de F, Pacheco-Filho EF, Perei- ra AFM, Romanos MTV, et al. Efficacy of red propolis hydro-alcoholic extract in controlling Streptococcus mutans biofilm build-up and dental enamel demineralization. Arch Oral Biol. 2018;93:56-65. 